\title{
A comprehensive review of the fuel cells technology and hydrogen economy.
}

\author{
ALI, D.M. and SALMAN, S.K.
}

2006

(C) 2006 IEEE. Personal use of this material is permitted. Permission from IEEE must be obtained for all other uses, in any current or future media, including reprinting/republishing this material for advertising or promotional purposes, creating new collective works, for resale or redistribution to servers or lists, or reuse of any copyrighted component of this work in other works. 


\title{
A COMPREHENSIVE REVIEW OF THE FUEL CELLS TECHNOLOGY AND HYDROGEN ECONOMY
}

\author{
D. Morsi Ali, S.K. Salman \\ Robert Gordon University, UK
}

\begin{abstract}
The degrading of the air quality resulting from the emissions of the existing energy conversion devices, in addition to the recent instability of the oil prices forced the need to a more stable zero-emission distribution generation technology or combination of technologies which allows a clean, cost effective supply of energy, on demand on a large scale and in any location. Thus, renewable energy generation or the decentralized power systems like wind, photovoltaic, as well as new hydrogen and fuel cells technologies are developing nowadays to take over from fossil hydrocarbons combustion. Fuel cell is an emerging technology which could allow a clean, cost effective supply of energy on demand on a large scale and in any location. This paper will act as a literature survey to the fuel cell technology. It will introduce the different fuel cell types with their advantages and disadvantages, and their suitability for different applications. It will also discuss the technical and economic issues facing the spread of this technology, and how to move to a worldwide hydrogen technology. It will also brief the current state of fuel cells with both drivers and barriers to its market growth. Further recommended work for the advance and spread of use of the fuel cells will be also highlighted.
\end{abstract}

KEYWORDS: Renewable Energy, Fuel cells, fuel cells' applications, Hydrogen Economy, Clean Environment.

\section{INTRODUCTION}

Fuel cells can potentially replace conventional power equipment in many cases as stationary power generation, transportation and battery replacement. They are already commercially available, at high costs, for applications such as portable power sources and small-scale power generation and transportation. At present there are different fuel cell types at various stages of intensive development by several manufacturers around the world. As fuel cells reduce the dependence on fossil fuels thus having a significant environmental and national security, they are the centre of interest for excessive research.

\section{WHAT IS A FUEL CELL?}

A fuel cell is a device that directly converts the chemical energy of a gaseous fuel into electrical energy. Any fuel (solid, liquid, or gas) can be used in fuel cells; however it should pass first through a reformer to get out pure hydrogen [1,2 and 3]. The fuel cell is analogous to a battery however battery reactants are stored internally and when used up battery must be replaced or recharged, while reactants of fuel cells are stored externally and can easily be recharged. Like a battery each fuel cell has two electrodes and an electrolyte that allows protons to pass through while blocking electrons [4]. Generally hydrogen is fed to the anode where it splits into a proton and electron; the protons pass through the electrolyte to the cathode while electrons are forced around an external circuit creating electricity. The hydrogen protons and electrons combine with oxygen from air at cathode producing pure water and a small amount of heat. The fuel cell reactions [5]:

At Anode: $\quad 2 \mathrm{H}_{2} \rightarrow 4 \mathrm{H}^{+}+4 \mathrm{e}^{-}$

At Cathode: $\quad \mathrm{O}_{2}+4 \mathrm{H}^{+}+4 \mathrm{e}^{-} \rightarrow 2 \mathrm{H}_{2} \mathrm{O}$

Overall reaction: $2 \mathrm{H}_{2}+\mathrm{O}_{2} \rightarrow 2 \mathrm{H}_{2} \mathrm{O}$

Fuel cells differ from the internal combustion engine (ICE). The ICE first converts fuel energy to thermal energy by combusting fuel with oxygen at high temperatures $\mathrm{T}_{\mathrm{H}}$ then the thermal energy is used to generate mechanical energy and some of the heat energy is rejected to a heat sink at a low temperature $T_{L}$, thus its efficiency is subject to the Carnet efficiency limitation; while fuel cells directly convert fuel chemical energy into electrical energy. The voltage produced from one cell is $(0-1 \mathrm{~V})$; for higher voltages a number of cells are stacked in series.

\section{HISTORY OF FUEL CELLS}

Sir William Grove developed the first fuel cell in 1839 . The principle was discovered by accident during an electrolysis experiment, when he disconnected the battery from the electrolyser and connected the two electrodes together he found a current flowing in the opposite direction consuming the gases of hydrogen and oxygen; he called this the "Gas-Battery". In 1842 he connected a number of gas batteries in series to form a "gas chain" and used the electricity produced to power an electrolyser in order to split water into hydrogen and oxygen.

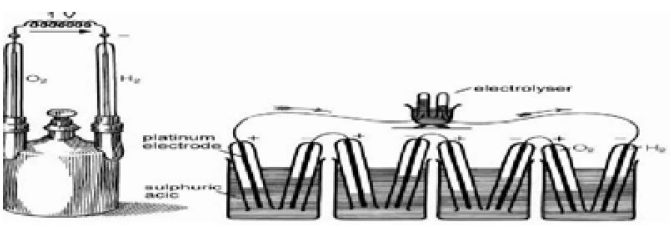

Fig.1, Grove's gas battery (1839) produced a voltage of about 1V

Francis Bacon at Cambridge University then produced the first practical fuel cell in 1950, which was alkaline $[5,6$, 7 , and 8]. As fuel cells produce several times more energy per equivalent unit weight than batteries, in 1960's the International fuel cells in Windsor developed a fuel cell power plant for the Apollo spacecraft to provide both electricity and drinking water for the astronauts on their journey to the moon. In the 1970's, International fuel cells developed a more powerful alkaline fuel cell for NASA's 
space shuttle Orbiter to supply all the electrical needs as well as drinking water [9].

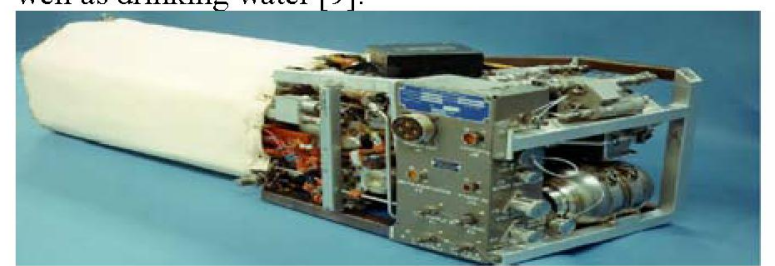

Fig. 2. NASA's space shuttle Orbiter fuel cell

Because of the complexity of isolation of carbon dioxide from alkaline electrolyte in fuel cells, most fuel cells developers after that focused their attention on developing other new non-alkaline types of electrolytes [10].

\section{KINDS OF FUEL CELLS}

Fuel cells can be classified by a diverse range of categories such as use, temperature, fuel type, oxidiser type, or charge carrier; however the most common is by the electrolyte type [11, 12 and 13]:

1. Solid Polymer electrolyte or Proton exchange membrane FC (PEM): The membrane used in here is polymer. It has low operating temperatures below $120^{\circ} \mathrm{C}$ by polymer properties and for water management for membrane hydration. The low temperature means that only hydrogen rich gas with the minimal $\mathrm{CO}$ (poison) can be used as a fuel. PEM fuel cells delivers high power density, rapid start-up, offers low weight and cost, and contain no corrosive fluids which make them ideal for transport applications, smaller units for powering laptops and other low power devices.

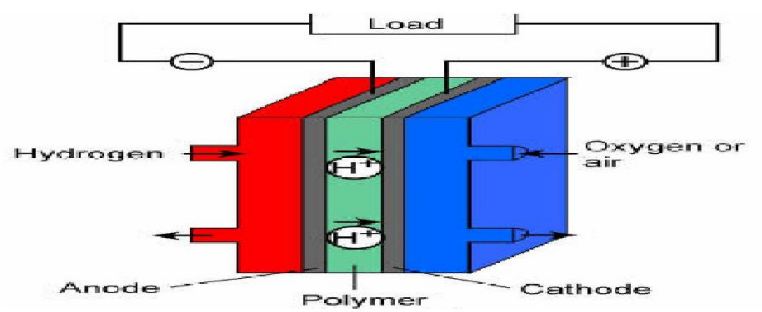

Fig. 3. A single PEM fuel cell

2. Alkaline FC (AFC): The electrolyte is concentrated potassium hydroxide. AFC was the first type of fuel cells developed and is still used in the space shuttles. These cells require a hydrogen supply containing no other reactive constituents, which result in their high cost.

3. Phosphoric acid FC (PAFC): The electrolyte is 100\% concentrated phosphoric acid. It operates at temperatures in the range of 150 to $220^{\circ} \mathrm{C}$. Water management is simpler than in AFC as of the use of $100 \%$ concentrated acid. PAFC was the first to reach commercialisation; it offers the lowest cost per $\mathrm{kW}$. However, development interest is dropping off.

4. Molten Carbonate (MCFC): The electrolyte here is usually a combination of alkali carbonates. The FC operates at 600 to $700{ }^{\circ} \mathrm{C}$ where the alkali carbonates form a highly conductive molten salt. MCFC offers higher electrical efficiencies than PAFC plus the possibility of cogeneration (water heating) which makes an overall efficiency of $80 \%$ feasible.
5. Solid Oxide (SOFC): The electrolyte is a solid nonporous metal oxide. Cells operate at 650 to $1000{ }^{\circ} \mathrm{C}$. The high temperatures allow internal reforming and result in by-product heat suitable for use directly in standard steam turbine bottoming cycles. Cogeneration plants of $80 \%$ overall efficiency are in operation.

\section{Direct Methanol Fuel Cell (DMFC):}

The direct methanol fuel cell has the advantage over the hydrogen fuel cell in that they can use a liquid fuel which means no need for external reforming, easier storage, and higher energy density. This fuel cell also uses a PEM membrane; however other catalysts in addition to platinum are required on the anode side to break the methanol bond into carbon dioxide, hydrogen ions and free electrons. At present the direct methanol fuel cells suffers from relatively low efficiency and high cost owing to the required platinum loading compared to that of the hydrogen cell.

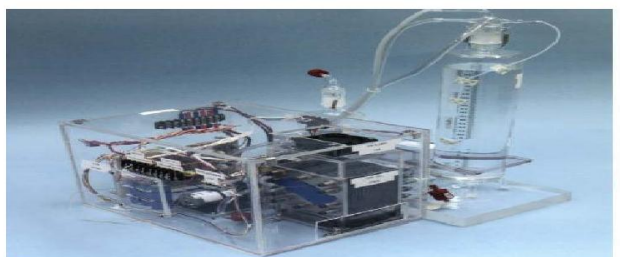

Fig. 4 a prototype direct methanol fuel cell provides up to 20 watts electrical power

\section{WHY FUEL CELLS?}

Fuel cells combine the best features of engines and batteries; like an engine they can operate for as long as fuel is available and like a battery they produce electricity directly from fuel without combustion (reducing emissions and noise) and without intermediate steps (efficient). Thus fuel cells will be replacing engines and supplementing batteries in a variety of applications in the future as long as they can demonstrate that they are equally reliable and cost competitive. Some of the main advantages of the fuel cells are $[14,15,16$ and 17]:

1. They convert hydrogen and oxygen directly into electricity and water and heat with no combustion resulting in an efficiency which is double that of an internal combustion engine (ICE).

2. They emit low levels of pollutants thus contributing substantially to a global low carbon dioxide economy.

3. They are quiet with no noise pollution.

4. They involve few moving parts hence require less maintenance.

5. They are modular. They can be made in a huge range of sizes, ranging from those producing quite small amounts of electric power for devices such as portable computers right up to very high powers for electric power stations.

6. They contribute to energy security concerns by allowing a wider choice of fuels.

7. They provide essential intermediate and final components of any future hydrogen economy.

8. They store electrical energy when no energy is needed (unlike batteries which need to be recharged), 
thus there is no power loss when system is switched off.

9. They provide promising automotive applications for a better environment.

10. They supply several times energy per equivalent unit weight than batteries, thus they are used for space applications.

11. They can potentially offer an attractive solution for back-up power applications.

12. They can be used as an emergency or even a stand alone power supply where the cost is less important than security.

13. They can be promising in some deserted region of the world by bringing there the technology and the skills to handle it.

\section{Their main drawbacks are:}

1. The cost is high compared to the price of present day alternatives

2. No infrastructure for mass-market availability of hydrogen, or methanol fuel.

3. The low output voltage for the power may need power electronics devices to be added to the overall system as an interface between the $\mathrm{FC}$ and the load thus complicating its design.

4. The slowness of reaction which makes it unable to meet fast-variation loads.

\section{WORLDWIDE HYDROGEN ECONOMY \& THE SAFETY OF HYDROGEN}

To create a worldwide hydrogen economy with fuel cells providing clean safe electrical energy to be used on board of vehicles, at neighbourhood fuelling stations, in electronic portable devices as well as in stationary installations to provide electricity for homes \& business a confirmation about the safety of hydrogen and the fuel cell systems that rely on it should be first achieved.

Fears came from Hydrogen explosiveness and flammability potential stems that resulted from hydrogen bombs $[18,19,20$ and 21]. Also fears came from the cause of the Hindenburg airship destroyed by fire in New Jersey. But examinations suggested that the airship did not explode but rather burned in omni directional patterns as a result of static electricity and not from a leak in hydrogen tank. The blue glow of electrical activity witnessed before the fire started indicates an extremely high temperature typical to a corona discharge; and the colour of fire wasn't characteristic of hydrogen. The National Hydrogen Association (NHA) also explains that to induce the nuclear fusion reaction of a hydrogen bomb, the rare $\mathrm{H}_{2}$ isotope, tritium, plus extreme heat are necessary and this has no resemblance to the simple chemical reactions associated with fuel cells.

The basic properties of hydrogen in light of safety in handling include [22]:

1. Hydrogen is lighter than air and diffuses rapidly. Its rapid dispersion rate is its greatest safety asset.

2. Hydrogen flames have low radiant heat which can reduce the risk of secondary fires.

3. It does not explode when ignited as a result of putting it under pressure or low temperature (in compressed tanks). It quickly rises and dissipates.

\section{WHERE WILL HYDROGEN COME FROM?}

1. Reformation of hydrocarbons: Because of the availability of methanol and propane, and the lack of hydrogen infrastructure, hydrocarbons are expected to be dominant fuels for stationary fuel cells applications. However, the emission of carbon dioxide from the reformation may contribute in the global warming.

2. Renewable Energy Systems: Hydrogen can be produced with no emission of carbon dioxide from renewable energy systems. A use of a solar panel, a wind turbine or a micro-hydro generator to produce electrical power which drives an electrolyser that breaks water producing hydrogen and oxygen gases, hydrogen is stored to be used in the fuel cell.

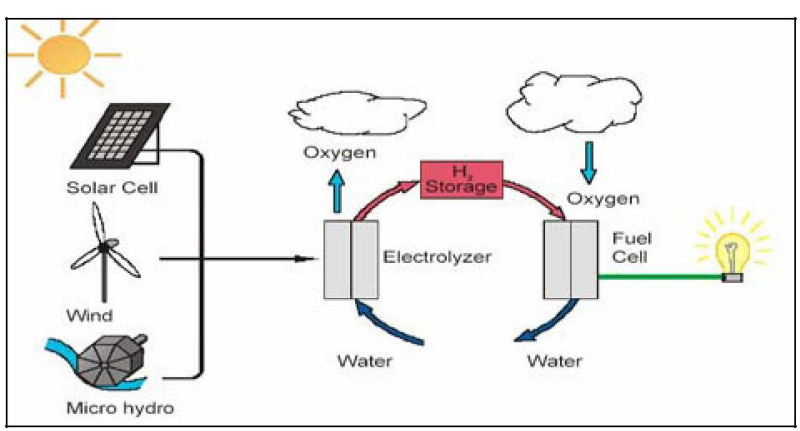

Fig.5. Electrical power from renewable energy sources

Thus anytime the sun shines, the wind blows or water flows the electrolyser can produce hydrogen. This is a closed system as none of the products or reactants (water, hydrogen and oxygen) are lost to the outside environment.

3. Biological Methods: Biogases produced from biomass, landfill, or anaerobic digestion contain mixtures of methane, $\mathrm{CO}_{2}$, and nitrogen together with varies organic materials are attractive to fuel cells. Also Bio liquids such as methanol and ethanol are attractive for some fuel cell systems.

\section{FUEL CELLS APPLICATIONS AND USES}

This includes the following applications [23 - 33]:

\section{Military:}

The efficiency, versatility, extended running time and quiet operation make fuel cells ideal for the power needs of military services from portable handheld devices used in the field to land and sea transportation and would dramatically reduce the level of fuel required during manoeuvres.

\section{Space:}

The combination of low weight, reliable supply of electricity and heat without significant noise and vibration and the added advantage of drinking water production gave fuel cells considerable advantages in space applications. 


\section{Portable:}

Miniaturised fuel cells will offer key advantages over conventional batteries such as increased operating times, reduced weight and ease of recharging. Direct methanol fuel cells (DMFC) offers a great advantage over solid batteries in that recharging will just involve refilling with the liquid fuel, not plugging into an external electric supply. Its disadvantage is the cost of the platinum catalyst required.

\section{Residential:}

These are smaller units typically below $50 \mathrm{~kW}$. All the heat and power requirements of private households or small business could be met by a low temperature PEMFC or a cheaper PAFC. At present only few homes in the USA, Japan and Germany are powered by PEM cells.

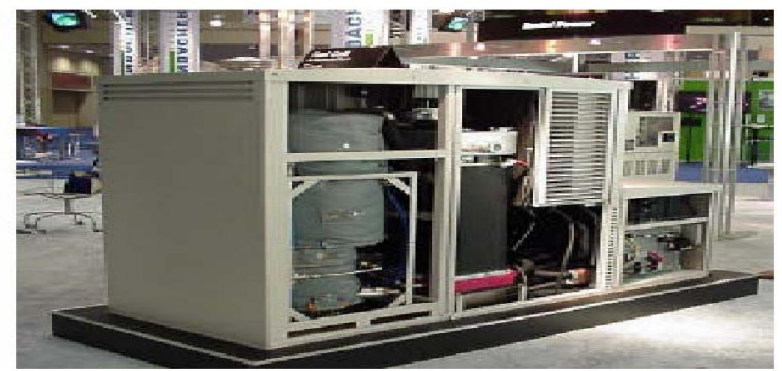

Fig. 6 A fuel cell cogeneration power plant for residential applications, supplies $5 \mathbf{k W}$

\section{Stationary:}

The efficiency and the reduced emission of fuel cells with respect to traditional fossil fuels based supplies, makes it an attractive option. Furthermore, the standalone aspect of the technology makes it useful in areas not served by a national power grid or where backup power is required. So far manufactures have focused applications at a range of sites including schools, office blocks and banking facilities. In future high temperature fuel cells, such as MCFC and SOFC, may be adapted for MW-scale power generation. The high operating temperatures (600$1100^{\circ} \mathrm{C}$ ) cells can tolerate a contaminated source of hydrogen and hence can use unreformed natural gas, diesel or gasoline. Also, the heat generated can be used to produce additional electricity by driving steam turbines.

\section{Transportation:}

National and State authorities around the world have introduced legislation that forces automobile manufacturers to supply vehicles that produce greatly reduced emissions. Fuel cell technology offers an opportunity to meet this requirement. Research by the "Pembina Institute" has shown that the amount of carbon dioxide produced from a small car can be reduced by as much as $72 \%$ when powered by a fuel cell running on hydrogen reformed from natural gas instead of gasoline ICE. However, for fuel cells to replace ICE then they must be able to reach operating temperature rapidly, provide competitive fuel economy and give a responsive performance. PEM fuel cells are best placed to meet all requirements with their high power density, their solid polymer electrolyte which helps to minimize potential corrosion, their low operating temperature $\left(80^{\circ} \mathrm{C}\right)$ that makes them reach the operating temperature quickly, their rapid response to varying loads that raise their efficiency to $60 \%$ where the ICE efficiency is $25 \%$. PEM fuel cells need an uncontaminated hydrogen fuel.

\section{THE MARKET FOR FUEL CELLS}

The fuel cell market has only just begun to emerge with few FC in operation. Drivers and barriers for the market growth can be summarised as follows.

\subsection{Drivers for Market Growth:}

- Favourable Characteristics: Their high efficiency, good part load characteristics, rapid load flowing, flexibility of fuel supply and flexibility of load factor gives fuel cells a strong position in a wide range of applications.

- Government market stimulation programs: The growing scientific consensus that increasing levels of greenhouse gas emissions are changing the earth's climate, forced programmes for clean energy (currently mainly for transport applications).

- Oil Reserves: As no one can predict what will happen to the world wide oil demand and prices, this has led the world's financial institutions to take an interest making vast amounts of capital available for the development and marketing of other energy sources such as fuel cells.

\subsection{Barriers to market Growth:}

- Cost: competition in the power generation market is fierce with $\cos t / \mathrm{kW}$.

- Institutional Inertia: the very highly developed carbon based economy means that the transition to a hydrogen economy will not happen fast until the technology is sufficiently developed to force the change.

- A hydrogen infrastructure must be developed in order to for hydrogen technologies to spread; but a hydrogen infrastructure will not develop until there is a sufficiently large adoption of hydrogen technologies.

\subsection{Market Sectors:}

- Standalone Power Generation - large (kW \& MW) scale plants.

- Integrated Power Generation - variable scale plants using solar and wind technology combined with water electrolysis plant and fuel cells to provide totally clean renewable energy.

- Transport

- Mobile - small scale (W) plant for portable electric and electronic equipments.

- $\quad$ Space \& Military - very high specification variable scale plant for transport, mobile power generation and small scale uses.

The available fuel cells in production today are capable to fulfil the needs of most the energy market sectors. Low temperature PEMFC is used for portable and transport applications. In the Power Generation Sector, PAFC remains popular for large Stationary Power applications 
with MCFC taking second place. Meanwhile, there are also a number of companies developing PEMFC and $\mathrm{SOFC}$, so the future dominance of any particular technology in this sector is still not determined.

\section{CURRENT STATE OF FUEL CELLS}

The number of complete systems (defined as a unit capable of independent power production) since 1995 up till 2004 is slightly over 10,000 . Recently, there was an increase in the importance of DMFC Also, apart from the continued romance with PEM units, SOFC exhibited a continued importance especially in stationary units [34].

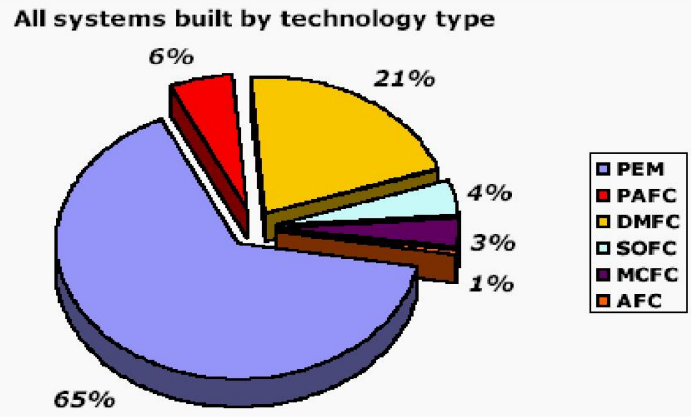

Portable Power continued to be an area of great interest, the market grew by roughly $75 \%$. Hitachi demonstrated a prototype PDA early in 2004; KDDI is looking to use Hitachi technology to launch mobile phones within two years; Casio has demonstrated a laptop containing a methanol reformer and a PEMFC and Samsung showed off portable computer with a ten hour runtime.

One of the most interesting developments in Stationary Power applications was the General Motor's project with Dow Chemical in Texas where four PEM fuel cells were installed to power its facilities. The ultimate plan is to install up to 400 cells to generate over $35 \mathrm{MW}$ of electricity from 2006.

For small stationary FC, there is a growing interest in the UPS (uninterruptible power supply) and backup power markets. In the military fuel cell market, the first real military product was in the form of the fuel cell submarines manufactured by $\mathrm{HDW}$. The number of systems built for other applications is still relatively low. The transportation applications again received the majority of interest. It focused on the PEM for propulsion. Light duty vehicles and buses currently have a realistic choice between direct hydrogen and natural gas, and niche transport has a broader spectrum including bio fuels and propane. The Fuel cell buses developed within the CUTE (Clean Urban Transport for Europe) project, regarded a great success in London.

Hydrogen Infrastructure also received positive boots in California and Canada. Also the number of companies coming into the fuel cell market, either as stack manufacturers, distributors, or otherwise has continued to grow.

\section{CONCLUSION}

This paper gives a full literature survey to the fuel cell technology. In order to help the move to a hydrogen economy, further work is recommended to simulate the Fuel Cell dynamic performance. As it is clear from the given survey, PEMFC has high power densities, high efficiencies, rapid start-up, long cell and stack life, low weight and cost, contain no corrosive fluids, useful for almost all applications, exhibit most of the basic fuel cell properties and finally incorporates the essential physical and electrochemical processes that happen in a fuel cell along its operation. Thus developing a reliable model for the simulation, and performance evaluation of PEMFC is recommended as a further work.

\section{REFERENCES}

1. www.fuelcell knowledge.org

2. www.fuel cells.org

3. "An introduction to fuel cell technology and economics", Nigel Brandon and David Hart, Centre for Energy Policy and Technology, 1999.

4. "A Back-up Power Solution with No Batteries", Mike L Perry and Steve Kotso, INTELEC 2004 Proceedings, pp.210-217.

5. "An Introduction to Fuel Cells and Hydrogen Technology", Brian Cook, April 2002.

6. "Fuel Cells Cradle to Grove", International Fuel Cells, June 2001.

7. "Control of Fuel Cell Power Systems", Jay T. Pukrushpan, Anna G. Stefanopoulou, Huei Peng.

8. "Review of the solid oxide fuel cell SOFC VIII Forum, Paris, France", Fuel cell today.com, 2003.

9. www.hq.nasa.gov/office/codeq/doctree/87

10. www.dodfuelcell.com/index.html

11. www.bullnet.co.uk/Hydrogen Fuel Cells

12. www.education.lanl.gov/resources/fuelcells.

13. www.irf.com

14. www.fuelcell store.com

15. www.pembina.org

16. www.icept.ic.ac.uk

17. www.fuelcelluk.org

18. www.eere.energy.gov/hydrogenandfuelcells/annual_ report04 safety.html.

19. www.hydrogensafety.info/articles/02-dec-03.asp.

20. www.tisec.com/products/hydrogen_sourcebook/hydr ogen_sourcebook.htm

21. www.esdjournal.com/articles/hindenbrg.

22. www.eere.energy.gov/hydrogenandfuelcells/codes/st andards organisation.html.

23. www.pnl.gov/fuelcells/newsletter.

24. www.nferc.uci.edu/

25. www.transportation.anl..gov/ttrdc/greet/

26. www.epa.gov/

27. www.ballard.com/

28. www.ifc.com/

29. www.fuelcellenergy.com/

30. www.metallicpower.com

31. www.aluminium-power.com

32. http://chem.ch.huji.ac.il/ eugeniik/

33. www.fuel-cell-bus-club.co.

34. www.fuelcell today.com. 